\title{
Myocardial Infarction Causes Transient Cholinergic Transdifferentiation of Cardiac Sympathetic Nerves via gp130
}

\author{
(1)Antoinette Olivas, ${ }^{1 *}$ Ryan T. Gardner, ${ }^{1,2 *}$ (ianguo Wang, ${ }^{3}$ Crystal M. Ripplinger, ${ }^{3}$ William R. Woodward, ${ }^{1}$ \\ and Beth A. Habecker ${ }^{1,2}$ \\ ${ }^{1}$ Department of Physiology and Pharmacology and ${ }^{2}$ Knight Cardiovascular Institute, Oregon Health and Science University, Portland, Oregon 97239, and \\ ${ }^{3}$ Department of Pharmacology, University of California, Davis, California 95616
}

Sympathetic and parasympathetic control of the heart is a classic example of norepinephrine (NE) and acetylcholine (ACh) triggering opposing actions. Sympathetic NE increases heart rate and contractility through activation of $\beta$ receptors, whereas parasympathetic ACh slows the heart through muscarinic receptors. Sympathetic neurons can undergo a developmental transition from production of NE to ACh and we provide evidence that mouse cardiac sympathetic nerves transiently produce ACh after myocardial infarction (MI). ACh levels increased in viable heart tissue 10-14 d after MI, returning to control levels at $21 \mathrm{~d}$, whereas NE levels were stable. At the same time, the genes required for ACh synthesis increased in stellate ganglia, which contain most of the sympathetic neurons projecting to the heart. Immunohistochemistry $14 \mathrm{~d}$ after MI revealed choline acetyltransferase (ChAT) in stellate sympathetic neurons and vesicular ACh transporter immunoreactivity in tyrosine hydroxylase-positive cardiac sympathetic fibers. Finally, selective deletion of the ChAT gene from adult sympathetic neurons prevented the infarction-induced increase in cardiac ACh. Deletion of the gp130 cytokine receptor from sympathetic neurons prevented the induction of cholinergic genes after MI, suggesting that inflammatory cytokines induce the transient acquisition of a cholinergic phenotype in cardiac sympathetic neurons. Ex vivo experiments examining the effect of $\mathrm{NE}$ and $\mathrm{ACh}$ on rabbit cardiac action potential duration revealed that ACh blunted both the NE-stimulated decrease in cardiac action potential duration and increase in myocyte calcium transients. This raises the possibility that sympathetic co-release of ACh and NE may impair adaptation to high heart rates and increase arrhythmia susceptibility.

Key words: cholinergic; cytokine; myocardial infarction; sympathetic; transdifferentiation

Significance Statement

Sympathetic neurons normally make norepinephrine (NE), which increases heart rate and the contractility of cardiac myocytes. We found that, after myocardial infarction, the sympathetic neurons innervating the heart begin to make acetylcholine (ACh), which slows heart rate and decreases contractility. Several lines of evidence confirmed that the source of ACh was sympathetic nerves rather than parasympathetic nerves that are the normal source of ACh in the heart. Global application of NE with or without ACh to ex vivo hearts showed that ACh partially reversed the NE-stimulated decrease in cardiac action potential duration and increase in myocyte calcium transients. That suggests that sympathetic co-release of ACh and NE may impair adaptation to high heart rates and increase arrhythmia susceptibility.

\section{Introduction}

Autonomic control of the heart is one of the best characterized examples of sympathetic and parasympathetic nerves triggering opposing actions in a target organ. Cardiac sympathetic neurons release norepinephrine (NE) to increase heart rate and force of contraction via activation of $\beta 1$ adrenergic receptors $(\beta 1 \mathrm{AR})$ on sino-atrial node cells and cardiac myocytes. In contrast, parasym-

\footnotetext{
The authors declare no competing financial interests.

${ }^{*}$ A.O. and R.T.G. contributed equally to this work.

Correspondence should be addressed to Dr. Beth A. Habecker, Department of Physiology and Pharmacology, L334, Oregon Health and Science University, 3181 SW Sam Jackson Park Rd, L334, Portland, OR 97239. E-mail: habecker@ohsu.edu.

DOI:10.1523/JNEUROSCI.3556-15.2016

Copyright $\odot 2016$ the authors $\quad 0270-6474 / 16 / 360479-10 \$ 15.00 / 0$ 
pathetic nerves release acetylcholine (ACh) to slow the heart and decrease contractility via activation of $\mathrm{M} 2$ muscarinic ACh receptors (mAChR). The first demonstration of neural plasticity used these opposing actions of NE and ACh on myocytes to identify a transition from noradrenergic to cholinergic transmission in sympathetic neurons cultured with cardiac myocytes (Furshpan et al., 1976). Follow-up studies using biochemical methods confirmed that sympathetic neurons could be either noradrenergic or cholinergic (Reichardt and Patterson, 1977) and that leukemia inhibitory factor (LIF) was the "cholinergic differentiation factor" released from myocytes that triggered the suppression of NE synthesis and induction of ACh production in cultured sympathetic neurons (Yamamori et al., 1989). A similar transition in neurotransmitter phenotype was identified in vivo in sympathetic neurons innervating developing sweat glands (Schotzinger and Landis, 1988, 1990) and periosteum (Asmus et al., 2000).

Several classes of growth factors have now been shown to stimulate the induction of cholinergic properties in sympathetic neurons, including cytokines such as LIF and cardiotrophin-1 (CT-1), which act through the gp130 receptor (Yamamori et al., 1989; Habecker et al., 1995; Stanke et al., 2006), as well as Neurotrophin-3 (NT-3) and Glial Cell Line-Derived Neurotrophic Factor (GDNF) (Brodski et al., 2000; Brodski et al., 2002; Hiltunen and Airaksinen, 2004; Apostolova et al., 2007). Many studies implicate target-derived factors in stimulating cholinergic sympathetic differentiation (Schotzinger and Landis, 1988, 1990; Asmus et al., 2000; Hiltunen and Airaksinen, 2004; Stanke et al., 2006), but other data suggest that sympathetic neurons can acquire a cholinergic phenotype during development in the absence of target interactions (Schäfer et al., 1997; Furlan et al., 2013). In contrast to developmental studies, however, the genes and proteins involved in cholinergic transmission have not been detected in sympathetic neuron cell bodies after axotomyinduced nerve injury (Boeshore et al., 2004; Brumovsky et al., 2011; Wojtkiewicz et al., 2013). Instead, inflammatory cytokines such as LIF (Rao et al., 1993; Sun and Zigmond, 1996) suppress noradrenergic properties and induce production of neuropeptides thought to be important for regeneration (Hyatt-Sachs et al., 1996; Klimaschewski et al., 1996; Zigmond and Sun, 1997; Brumovsky et al., 2011; Hesp et al., 2012; Wojtkiewicz et al., 2013).

These data and others led to the conclusion that sympathetic acquisition of cholinergic properties was confined to development. Factors such as LIF that suppressed NE and induced ACh in immature sympathetic neurons were thought to suppress NE but only induce neuropeptides in mature sympathetic neurons. However, a recent study examining cardiac sympathetic neuron phenotype in failing hearts - in which LIF and CT-1 are increased chronically-revealed gp130-dependent expression of cholinergic markers in tyrosine hydroxylase (TH)-immunoreactive stellate ganglion neurons (Kanazawa et al., 2010). Most of the sympathetic neurons in the stellate ganglia project to the heart, so this suggests that sustained retrograde signaling by cardiacderived cytokines induces cholinergic function in mature sympathetic neurons. In contrast to the extended time course of inflammation during heart failure, reperfusion of a blocked coronary artery during myocardial infarction (MI) leads to a large acute inflammatory response (Aoyama et al., 2000; Frangogiannis, 2012). Patients who survive an MI have a high risk of developing arrhythmias, especially during the first $30 \mathrm{~d}$ after MI (Solomon et al., 2005). Given the large inflammatory response after reperfusion and the opposing actions of ACh and NE on ion channels in cardiac myocytes, we investigated whether cardiac sympathetic nerves produced ACh after MI. Here, we provide evidence that adult cardiac sympathetic nerves transiently produce ACh after acute MI and that the induction of cholinergic genes requires gp130 expression in sympathetic neurons.

\section{Materials and Methods}

Mice. WT C57BL/6J were obtained from Jackson Laboratories. gp $130^{\mathrm{DBH}-\mathrm{Cre} / \mathrm{lox}}$ mice and inducible dopamine $\beta$ hydroxylase (DBHCreERT2) driver mice were generated as described previously (Stanke et al., 2006; Stubbusch et al., 2011) and were obtained from Dr. Hermann Rohrer (Max Planck Institute). Choline acetyltransferase (ChAT) is the enzyme that synthesizes ACh. To generate mice with adult sympathetic neurons that lack ChAT, we crossed DBH-CreERT2 mice with $\mathrm{ChAT}^{\text {lox/lox }}$ mice (Buffelli et al., 2003) that were obtained from Dr. Josh Sanes (Harvard University). Offspring that were homozygous for $\mathrm{ChAT}^{\text {lox/lox }}$ and expressed at least one copy of DBH-CreERT2 (ChAT ${ }^{\text {DBH-CreERT2/lox }}$ ) were treated with tamoxifen $(2 \mathrm{mg} / \mathrm{d}, \mathrm{i} . \mathrm{p}$.) for $7 \mathrm{~d}$ to stimulate expression of Cre recombinase and to generate mice with noradrenergic neurons that lacked ChAT (iChAT KO). Treatment of mice for $<7 \mathrm{~d}$ did not produce complete deletion of the ChAT gene in cardiac sympathetic neurons.

All mice were kept on a $12 \mathrm{~h}: 12 \mathrm{~h}$ light/dark cycle with ad libitum access to food and water. Male and female mice 12-18 weeks old were used for all experiments. Animals from differing genotypes were age and sex matched for each experiment. All procedures were approved by either the Oregon Health and Science University (OHSU) or the University of California-Davis Institutional Animal Care and Use Committee and complied with the Guide for the Care and Use of Laboratory Animals published by the National Academies Press (Ed 8). The experimental groups used were sham-operated animals and animals that underwent ischemia-reperfusion surgery, with tissue collection for both the sham and MI groups occurring at identical times after surgery. A minimum of four animals was assigned to each group for each experiment and tissue was processed together for each type of analysis.

Rabbits. Male New Zealand White rabbits were obtained from the Western Oregon Rabbit Company and kept on a 12 h:12 h light/dark cycle with ad libitum access to food and water.

Genotyping. A two-step PCR was used to genotype both the DBHCreERT2 and ChAT ${ }^{\text {lox/lox }}$ mice. For DBH-CreERT2 samples, forward (TCAGAGATACCTGGCCTG) and reverse (CTGAAGGGTCTGGTAGGA) primers were used with a $56^{\circ} \mathrm{C}$ annealing temperature, generating an 865 bp product. For $\mathrm{ChAT}^{\text {lox/lox }}$ samples, a common forward primer (GCCCTGCCAGTCAACTCTA) was used in combination with two different reverse primers. To identify the WT allele, the reverse primer GAAATCCTGACAGATTCCAACA was used and the product was $525 \mathrm{bp}$. To identify the mutant allele, the reverse primer TTTCCGCCTCAGGACTCTTC was used and the product was $400 \mathrm{bp}$. The annealing temperature was set at $60^{\circ} \mathrm{C}$ for both WT and mutant samples.

Heart rate analysis. Age-matched female WT and iChAT KO mice were intubated and anesthetized with $2 \%$ isoflurane. Heart rate was continuously monitored using subcutaneous electrodes in lead II configuration and body temperature was maintained at $37^{\circ} \mathrm{C}$. Heart rate was allowed to stabilize for $10 \mathrm{~min}$ once body temperature reached $37^{\circ} \mathrm{C}$ to determine the baseline rate. Mice were then given an intraperitoneal injection of 1 $\mathrm{mg} / \mathrm{kg}$ atropine (Sigma-Aldrich). Heart rate was again allowed to stabilize and $10 \mathrm{~min}$ of additional heart rate was recorded. Five minutes of heart rate data were averaged to determine baseline and atropineinduced heart rates.

Myocardial ischemia-reperfusion. Ischemia-reperfusion was performed as described previously (Parrish et al., 2010; Gardner and Habecker, 2013). Adult mice were placed in an induction chamber and anesthetized with 4\% isoflurane. Mice were intubated, mechanically ventilated, and maintained with $1-2 \%$ isoflurane mixed with $100 \%$ oxygen. Core body temperature was maintained at $\sim 37^{\circ} \mathrm{C}$ and a two-lead ECG was monitored throughout the surgery using a PowerLab data acquisition system (AD Instruments). A left lateral thoracotomy was performed in the fourth intercostal space and the pericardium was opened. The left anterior descending coronary artery (LAD) was reversibly ligated with an 8-0 suture for $45 \mathrm{~min}$ and then reper- 
fused by release of the ligature. Occlusion was confirmed with ST segment elevation, regional cyanosis, and wall motion abnormalities. Reperfusion was confirmed by the return of color to the myocardium distal to the ligation and disappearance of ST elevation. The suture remained within the wound for the identification of the ligature site and the chest and skin were closed in layers. After surgery, animals were returned to individual cages and given regular food and water until euthanasia and tissue harvest. Buprenorphine $(0.1 \mathrm{mg} / \mathrm{kg})$ was administered as needed to ensure that animals were comfortable after surgery. All surgical procedures were performed under aseptic conditions. Sham animals underwent the procedure described above except for the LAD ligation.

HPLC analysis of NE and mass spectrometry analysis of ACh. NE levels were measured by HPLC with electrochemical detection as described previously (Parrish et al., 2010) and ACh was quantified by mass spectrometry in the OHSU Bioanalytical Core facility as described previously (Hasan et al., 2012). Hearts were excised and cut in $2 \mathrm{~mm}$ transverse cross sections and the tissue below the site of LAD occlusion was separated into left and right ventricles (LV, RV). The LV was further dissected under a microscope into scar and viable (peri-infarct) tissue before freezing and storage at $-80^{\circ} \mathrm{C}$. Sham tissue underwent similar processing so that any ACh degradation by acetylcholinesterase during the dissection was comparable. Tissue samples from each heart were homogenized and neurotransmitters extracted at room temperature with $300 \mu \mathrm{l}$ of perchloric acid $(0.1 \mathrm{M})$ containing a $1.0 \mu \mathrm{M}$ concentration of the internal standard dihydroxybenzylamine to correct for NE sample recovery. Catecholamines were purified from $100 \mu \mathrm{l}$ of the supernatant by alumina extraction before analysis by HPLC. Detection limits were $\sim 0.05 \mathrm{pmol}$ with recoveries from the alumina extraction $>60 \%$. ACh was quantified in a second aliquot of $100 \mu \mathrm{l}$ that was filtered at $4^{\circ} \mathrm{C}$ before analysis on the mass spectrometer.

Immunohistochemistry. Hearts were fixed for $1 \mathrm{~h}$ and stellate ganglia for $15 \mathrm{~min}$ in $4 \%$ paraformaldehyde. Tissue was rinsed in PBS $(5 \times 5$ $\min$ ), cryoprotected in $30 \%$ sucrose overnight, and $10 \mu \mathrm{m}$ transverse sections were thaw mounted onto charged slides. To reduce fixativeinduced autofluorescence, heart sections were rinsed in $10 \mathrm{mg} / \mathrm{ml} \mathrm{so-}$ dium borohydride in PBS $3 \times 10 \mathrm{~min}$ and then rinsed in PBS for $10 \mathrm{~min}$. Sections were then blocked in $1 \%$ BSA/0.3\% Triton X-100 in PBS for $1.5 \mathrm{~h}$, incubated with rabbit anti-TH (1:300; Millipore), sheep anti-TH (1:300; Serotec), rabbit anti-ChAT (1:150; Proteintech), or goat antivesicular ACh transporter (anti-VAChT, 1:50; Promega) overnight, rinsed $3 \times 10 \mathrm{~min}$ in PBS, and incubated $1.5 \mathrm{~h}$ with donkey anti-rabbit, donkey anti-sheep, or donkey anti-goat Alexa Fluor secondary antibodies (1:500; Invitrogen). Sections were rinsed $3 \times 10 \mathrm{~min}$ in PBS. To reduce lipofuscin-induced autofluorescence, heart sections were treated with $10 \mathrm{~mm} \mathrm{CuSO}_{4}$ in $50 \mathrm{~mm} \mathrm{NH}_{4} \mathrm{C}_{2} \mathrm{H}_{3} \mathrm{O}_{2}$ for $30 \mathrm{~min}$. Slides were then dipped briefly in $\mathrm{mqH}_{2} \mathrm{O}$ and placed in $\mathrm{PBS}$, coverslipped, and visualized by fluorescence microscopy. Sections from sham and MI animals were stained and photographed side by side to minimize variation between the groups due to the immunohistochemistry procedure.

Real-time PCR. Stellate ganglia, which contain the majority of the sympathetic neurons that project to the heart, were harvested 7, 10, 14, or $21 \mathrm{~d}$ after sham or ischemia-reperfusion surgery and stored immediately in RNAlater. RNA was isolated from individual stellate ganglia using the Ambion RNAqueous micro kit. Total RNA was quantified by OD260 and then $200 \mathrm{ng}$ of total RNA was reverse transcribed and diluted for use. Real-time PCR was performed with ABI TaqMan Universal PCR master mix in the ABI 7500. Samples were assayed using ABI prevalidated TaqMan gene expression assays for mouse genes encoding the nuclear protein Satb2, with GAPDH as a normalization control, and the proteins required for cholinergic transmission: ChAT, the enzyme that synthesizes ACh; the high-affinity choline transporter $(\mathrm{CHT})$, which transports choline into the cell and is the rate-limiting step in ACh synthesis, and VAChT, which packages ACh into vesicles for release. For the PCR amplification, 2-4 $\mu$ l of RT reactions (representing $5 \mathrm{ng}$ of RNA template) were used in a total volume of $20 \mu \mathrm{l}$ and each sample was assayed in duplicate. Standard curves were generated with known amounts of RNA from brain, ranging from 0.8 to $100 \mathrm{ng}$. Values for ChAT, VAChT, CHT, and Satb2 were normalized to GAPDH from the same sample. Sham controls from different time points were identical and were combined into a single sham group.

Dual optical mapping of transmembrane potential and intracellular $\mathrm{Ca}^{2+}$. Langendorff perfusion of isolated rabbit hearts and optical mapping of transmembrane potential $\left(V_{\mathrm{m}}\right)$ and $\mathrm{Ca}^{2+}$ was performed as described previously (Myles et al., 2012). Briefly, male New Zealand White rabbits $(n=3)$ were anesthetized with an intravenous injection of pentobarbital sodium $(50 \mathrm{mg} / \mathrm{kg})$ containing $1000 \mathrm{IU}$ of heparin. After a midsternal incision, hearts were rapidly excised and perfused at $37^{\circ} \mathrm{C}$ with oxygenated $\left(95 \% \mathrm{O}_{2}, 5 \% \mathrm{CO}_{2}\right)$ modified Tyrode's solution containing the following (in mmol/L): $\mathrm{NaCl} 128.2, \mathrm{CaCl}_{2} 1.3, \mathrm{KCl} 4.7, \mathrm{MgCl}_{2}$ $1.05, \mathrm{NaH}_{2} \mathrm{PO}_{4} 1.19, \mathrm{NaHCO}_{3} 20$, and glucose 11.1, pH 7.4 \pm 0.05 . The flow rate $(25-35 \mathrm{ml} / \mathrm{min})$ was adjusted to maintain a perfusion pressure of 60-70 mmHg. Two $\mathrm{Ag} / \mathrm{AgCl}$ disc electrodes were positioned in the bath to record an ECG analogous to a lead I configuration. Bipolar pacing electrodes were positioned on the base of the LV epicardium for pacing, which was performed at a cycle length (CL), or pacing interval, of $300 \mathrm{~ms}$ using a $2 \mathrm{~ms}$ pulse at twice the diastolic threshold. Blebbistatin (Tocris Bioscience; $10-20 \mu \mathrm{M}$ ) was added to the perfusate to eliminate motion artifact during optical recordings. Hearts were loaded with the acetoxymethyl ester form of the fluorescent intracellular $\mathrm{Ca}^{2+}$ indicator Rhod-2 (Rhod-2 AM; Invitrogen; $0.5 \mathrm{ml}$ of $1 \mathrm{mg} / \mathrm{ml}$ in DMSO containing $10 \%$ pluronic acid) and subsequently stained with the voltage-sensitive dye RH237 (Invitrogen; $50 \mu \mathrm{l} \mathrm{of} 1 \mathrm{mg} / \mathrm{ml}$ in DMSO) via the coronary perfusion. The anterior epicardial surface was excited using LED light sources centered at $531 \mathrm{~nm}$ and band-pass filtered from 511 to $551 \mathrm{~nm}$ (LEX-2; SciMedia). The emitted fluorescence was collected through a THTmacroscope (SciMedia) and split with a dichroic mirror at $630 \mathrm{~nm}$. The longer wavelength moiety, containing the $V_{\mathrm{m}}$ signal, was long-pass filtered at $700 \mathrm{~nm}$ and the shorter wavelength moiety, containing the $\mathrm{Ca}^{2+}$ signal, was band-pass filtered with a $32 \mathrm{~nm}$ filter centered at $590 \mathrm{~nm}$. The emitted fluorescence signals were then recorded using two CMOS cameras (MiCam Ultima-L; SciMedia) with a sampling rate of $1 \mathrm{kHz}$ and $100 \times 100$ pixels with a $31 \times 31 \mathrm{~mm}$ field of view.

Baseline electrophysiological parameters were determined during epicardial pacing with a $300 \mathrm{~ms}$ CL (equivalent to $200 \mathrm{bpm}$ heart rate). To measure how the action potential duration (APD) and intracellular $\mathrm{Ca}^{2+}$ release adapt to sudden changes in heart rate, an APD restitution curve and $\mathrm{S} 2 / \mathrm{S} 1$ ratio of $\mathrm{Ca}^{2+}$ transient (CaT) amplitude were constructed by a standard S1-S2 pacing protocol in which 12 pacing stimuli were delivered at a $300 \mathrm{~ms}$ interval (S1) followed by a premature S2 stimulus. The S2 interval was gradually shortened until the effective refractory period was reached and the S2 stimulus failed to propagate an action potential (AP). Adrenergic effects on APD restitution and the refractoriness of $\mathrm{Ca}^{2+}$ release were investigated using $1.5 \mu \mathrm{M}$ NE in the perfusate. Combined adrenergic and cholinergic effects were investigated by adding 1.5 $\mu \mathrm{M}$ NE and 1.5 $\mu \mathrm{M}$ ACh to the perfusate. The sino-atrial node was removed to allow for pacing. Data analysis was performed using a commercially available analysis program as described previously (Myles et al., 2012). AP activation time was determined as the time at $50 \%$ between peak and baseline amplitude. APD at $90 \%$ repolarization $\left(\mathrm{APD}_{90}\right)$ was calculated as repolarization time - activation time from data collected during pacing at various S2s. APD restitution curves were constructed by plotting $\mathrm{APD}_{90}$ versus S2 coupling length. The ratio of S2 and S1 CaT amplitude was used to assess the refractoriness of $\mathrm{Ca}^{2+}$ release.

Statistics. Student's $t$ test was used for a single comparison between two groups. One-way ANOVA with a Dunnett's multiple-comparison post test was used to compare surgical groups with the sham control group from the same genotype. Two-way ANOVA with a Bonferroni post test was used to compare across two genotypes and treatment groups. The slopes of APD restitution curves were compared by linear curve fit and CaT curves were analyzed using nonlinear curve fit of the S2/S1 ratio using one-phase association. Statistical analyses were performed using Prism version 5.0 (GraphPad Software).

\section{Results}

To determine whether acute $\mathrm{MI}$ induced cholinergic function in cardiac sympathetic neurons, we first quantified NE and ACh content in the heart 10,14 , and $21 \mathrm{~d}$ after sham surgery or MI. 

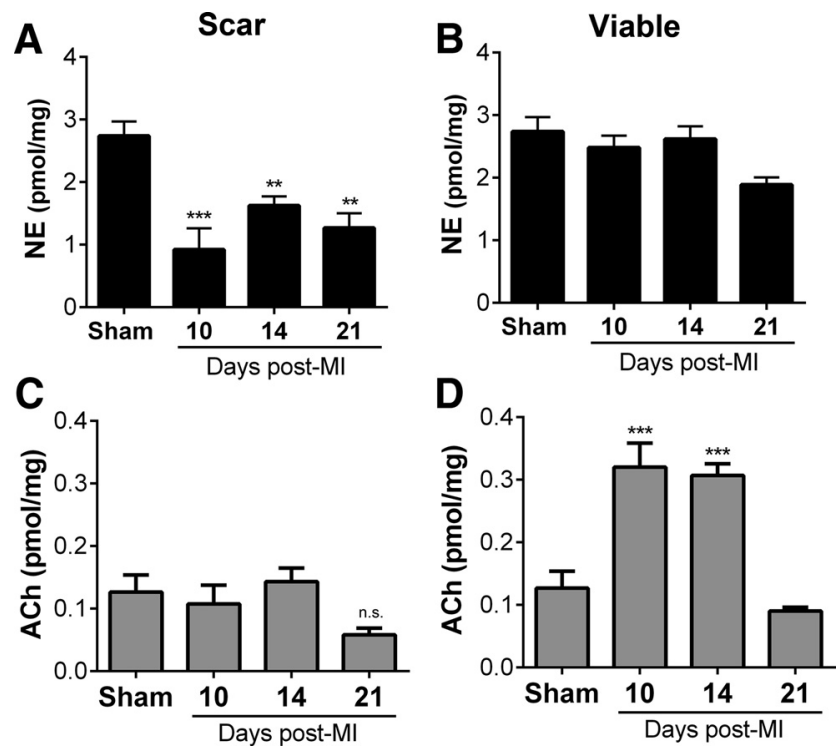

Figure 1. Differential changes in cardiac NE and ACh content after MI. NE and ACh were quantified in scar tissue $(\boldsymbol{A}, \boldsymbol{C})$ and viable peri-infarct myocardium $(\boldsymbol{B}, \boldsymbol{D})$. NE content in scar tissue $(\boldsymbol{A})$ decreased compared with sham tissue 10,14 , and $21 \mathrm{~d}$ after $\mathrm{MI}$, whereas NE in viable peri-infarct myocardium did not $(\boldsymbol{B})$. ACh content in the same scar tissue $(\boldsymbol{C})$ did not change after $\mathrm{Ml}$, but ACh content in viable peri-infarct tissue increased significantly 10 and $14 \mathrm{~d}$ after MI, returning to sham levels $21 \mathrm{~d}$ post-MI. Data are shown as means \pm SEM; $n=4-6$ except sham $n=9 ;{ }^{* *} p<0.01,{ }^{* * *} p<0.001$ compared with sham.

Our previous studies revealed a sustained loss of nerves in the cardiac scar $10 \mathrm{~d}$ after $\mathrm{MI}$, with normal innervation density and $\mathrm{NE}$ content in the viable left ventricle surrounding the scar (Gardner and Habecker, 2013). Therefore, we dissected scar tissue away from viable "peri-infarct" tissue and quantified NE and $\mathrm{ACh}$ in both regions from each heart. Levels of NE and ACh were identical among shams obtained 10, 14, and $21 \mathrm{~d}$ after surgery, so the shams were combined into a single group. NE content was decreased in the scar compared with sham (Fig. 1A), consistent with the loss of sympathetic nerve fibers, whereas ACh content remained unchanged (Fig. 1D). The innervated tissue outside of the scar exhibited NE levels similar to shams (Fig. 1B), whereas ACh levels were increased significantly 10 and $14 \mathrm{~d}$ after MI, returning to sham levels $21 \mathrm{~d}$ after MI.

The rise in ACh within the left ventricle is consistent with the induction of cholinergic function in sympathetic neurons, but could also be due to changes in the rare cholinergic parasympathetic nerves in the ventricle. To determine whether the increase in cardiac ACh was due to sympathetic nerves, we quantified expression of the genes required for cholinergic function in the stellate ganglia, which contain most of the sympathetic neurons projecting to the heart. Ganglia were collected 10, 14, and $21 \mathrm{~d}$ after MI from the same mice used for cardiac NE and ACh analysis in Figure 1. To gain additional insight into the time course of ACh induction, we also examined stellate ganglia that had been collected $7 \mathrm{~d}$ after MI for another study. The genes required for cholinergic transmission, the synthetic enzyme ChAT, the ratelimiting CHT, and VAChT, were present a similar levels in shams from each time point, so the shams were combined into a single group. ChAT and CHT mRNA levels were increased significantly 7, 10, and $14 \mathrm{~d}$ after MI (Fig. $2 A, B$ ), whereas VAChT mRNA was increased significantly 10 and $14 \mathrm{~d}$ after MI (Fig. 2C).

To confirm that the increased expression of cholinergic genes in sympathetic neurons led to production of the associated proteins, immunohistochemistry was performed in stellate ganglia
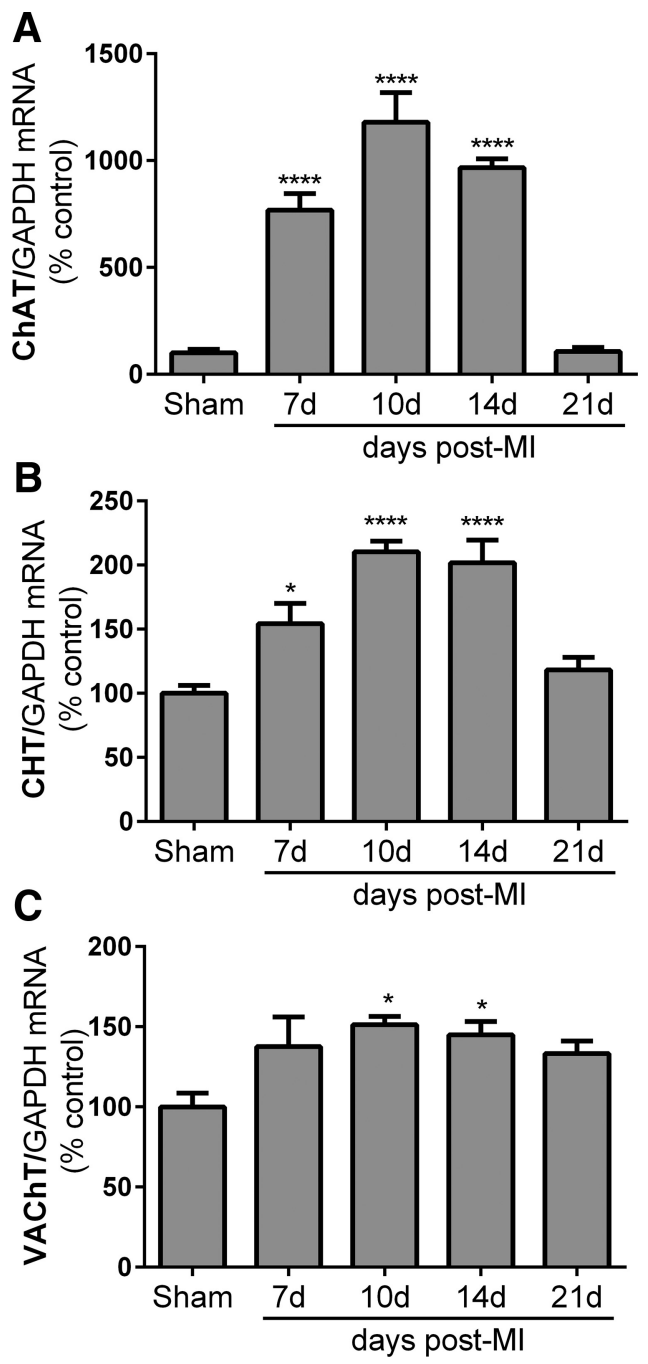

Figure 2. Ml induces expression of cholinergic genes in cardiac sympathetic neurons. Cholinergic genes were quantified in stellate ganglia 7, 10, 14, and $21 \mathrm{~d}$ after Ml and normalized to the associated sham controls. mRNA encoding $\mathrm{ChAT}(\boldsymbol{A}), \mathrm{CHT}(\boldsymbol{B})$, and VAChT $(\boldsymbol{C})$ were increased significantly after MI. Data are shown as means \pm SEM; $n=4-5$ except sham $n=6$; ${ }^{*} p<$ $0.05,{ }^{* * *} p<0.0001$ compared with sham.

and heart sections $14 \mathrm{~d}$ after MI, when cholinergic genes were elevated and ACh levels were high in the heart. Double-label immunohistochemistry confirmed coexpression of the ACh synthetic enzyme ChAT with $\mathrm{TH}$, the rate-limiting enzyme in NE synthesis, in sympathetic neuron cell bodies (Fig. 3). In contrast to the $\mathrm{TH}+/ \mathrm{ChAT}+$ neurons identified $14 \mathrm{~d}$ after MI, sham ganglia contained predominantly $\mathrm{TH}+/ \mathrm{ChAT}-$ sympathetic neurons surrounded by $\mathrm{TH}-/ \mathrm{ChAT}+$ preganglionic fibers. Heart sections were double labeled for TH and VAChT and, consistent with the presence of ChAT in sympathetic neuron cell bodies, $\mathrm{TH}+/ \mathrm{VAChT}+$ fibers were identified in heart sections $14 \mathrm{~d}$ after MI. In contrast, sham hearts contained only TH+/VAChTsympathetic fibers and rare $\mathrm{TH}-/ \mathrm{VAChT}+$ parasympathetic fibers.

Finally, to confirm that the rise in cardiac ACh observed after MI was due solely to increased ACh production in sympathetic neurons and not to changes in parasympathetic transmission, we generated mice in which the ChAT gene was deleted in adult sympathetic neurons. Adult mice homozygous for a ChAT $\mathrm{C}^{\text {lox/lox }}$ allelle (Buffelli et al., 2003) and expressing an inducible Cre recombinase driven by the dopamine $\beta$ hydroxylase promoter 

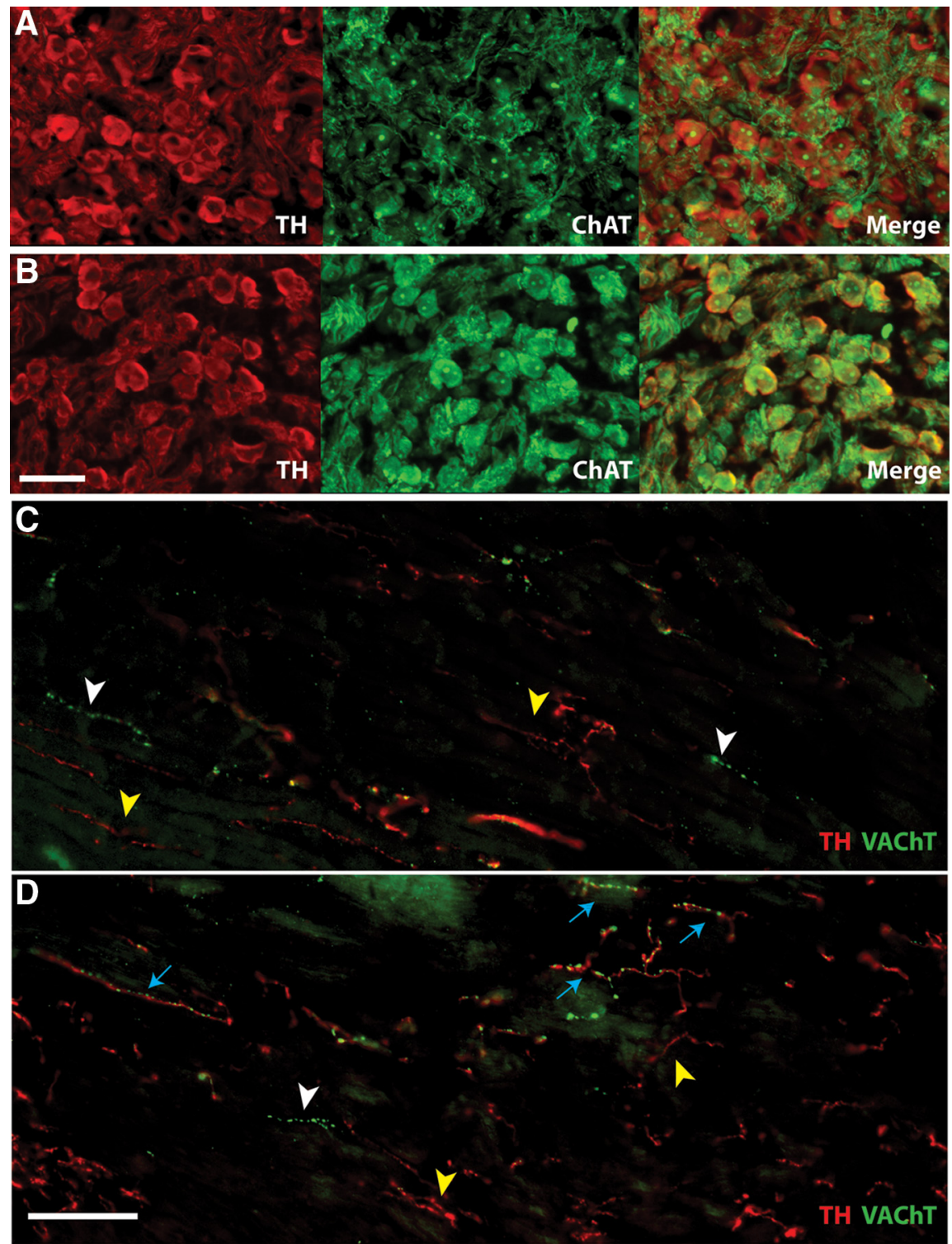

Figure 3. $\boldsymbol{A}, \boldsymbol{B}$, Stellate ganglion sections $14 \mathrm{~d}$ after sham $(\boldsymbol{A})$ or $\mathrm{MI}(\boldsymbol{B})$ stained for $\mathrm{TH}$ (red) to identify noradrenergic neurons and ChAT (green) to identify cholinergic neurons. Scale bar, $50 \mu \mathrm{m}$. In sham ganglia, only preganglionic fibers are positive for ChAT, whereas sympathetic cell bodies are $\mathrm{TH}+$. After Ml, however, $\mathrm{TH}+$ sympathetic neurons also express ChAT. C, D, Heart sections after sham $(\boldsymbol{C})$ or MI (D) stained for TH (red) and VAChT (green). Scale bar, $100 \mu \mathrm{m}$. Yellow arrowheads identify TH+/NAChT sympathetic fibers; white arrowheads identify TH - NAChT + parasympathetic fibers; blue arrows identify fibers positive for both noradrenergic and cholinergic markers, which were observed only after MI. Note that parasympathetic fibers are sparse in the left ventricle whereas sympathetic fibers are abundant.

(DBHCre-ERT2) (Stubbusch et al., 2011) were treated for $7 \mathrm{~d}$ with tamoxifen to drive deletion of the ChAT gene in noradrenergic neurons (iChAT KO). ChAT mRNA was near the limit of detection in WT sham ganglia, making it difficult to confirm deletion of the ChAT gene in stellates from unoperated iChAT KO mice. Therefore, we performed MI surgery to induce cholinergic genes in tamoxifen-treated mice and collected hearts and stellate ganglia $14 \mathrm{~d}$ after MI. Cholinergic gene expression and neurotransmitter levels were quantified and compared with the values obtained previously for WT mice $14 \mathrm{~d}$ after MI (Figs. 1, 2). Real-time PCR confirmed deletion of the ChAT gene in cardiac sympathetic neurons. ChAT mRNA levels in post-MI iChAT KO mice treated with tamoxifen were similar to the low levels present in WT sham mice, and significantly lower than ChAT mRNA in WT mice $14 \mathrm{~d}$ after MI, denoted by the dashed line in Figure $4 A$.
In contrast, the other cholinergic genes were expressed at high levels similar to those observed in WT post-MI mice rather than sham mice. Once deletion of ChAT mRNA was confirmed in stellate ganglia, neurotransmitter content was quantified in viable peri-infarct myocardium from the same mice. Deletion of ChAT from sympathetic neurons abolished the post-MI increase in cardiac ACh content, resulting in ACh levels significantly lower than WT post-MI hearts (Fig. $4 B)$ and similar to those in sham hearts (sham $0.127 \pm 0.03 \mathrm{pmol} / \mathrm{mg}, n=9$; $\mathrm{iChAT} \mathrm{KO} 0.065 \pm 0.02 \mathrm{pmol} / \mathrm{mg}, n=4)$. In contrast, NE levels, which should not be affected by deletion of ChAT in sympathetic neurons, were identical to values obtained earlier from WT mice $14 \mathrm{~d}$ after MI (Fig. 4B). This suggests that the increased ACh observed in the left ventricle after MI was due to production of ACh by sympathetic nerves rather than other sources.

Constitutive DBH-Cre driver lines can cause recombination in cardiac parasympathetic neurons due to transient expression of $\mathrm{DBH}$ in neural crest precursor cells (Parrish et al., 2009). Although this should not occur in the DBH-CreERT2 mice used for this study (Stubbusch et al., 2011), we confirmed retention of ChAT expression and ACh production in parasympathetic neurons by examining parasympathetic control of heart rate in unoperated WT and iChAT KO mice. Basal heart rate was the same in both genotypes and blockade of cholinergic transmission with atropine generated an identical increase in heart rate (Fig. 4C), confirming intact parasympathetic transmission in iChAT KO hearts.

Several different classes of growth factors can induce cholinergic function in sympathetic neurons, including cytokines that act via gp130 signaling, NT-3, and GDNF (Yamamori et al., 1989; Brodski et al., 2000; Brodski et al., 2002; Stanke et al., 2006). NT-3 expression is unchanged in the heart after ischemiareperfusion (Hiltunen et al., 2001), whereas GDNF levels are low in adult heart (Miwa et al., 2010) and have not been examined after injury. In contrast, gp130 cytokines such as LIF and CT-1 are elevated in the left ventricle after MI (Aoyama et al., 2000; Gritman et al., 2006), where they affect the remodeling of cardiac myocytes (Haghikia et al., 2011; Oba et al., 2012) and trigger the local loss of TH from sympathetic nerves via proteasomal degradation (Parrish et al., 2010; Shi and Habecker, 2012). We hypothesized that cytokine activation of gp130 was responsible for the induction of cholinergic function in cardiac sympathetic neurons after MI. To test that hypothesis, we quantified expression of the genes associated with cholinergic transmission in stellate ganglia from WT mice and mice with noradrenergic neurons that lack gp130 (gp130 KO). Cytokine stimulation of cholinergic function 

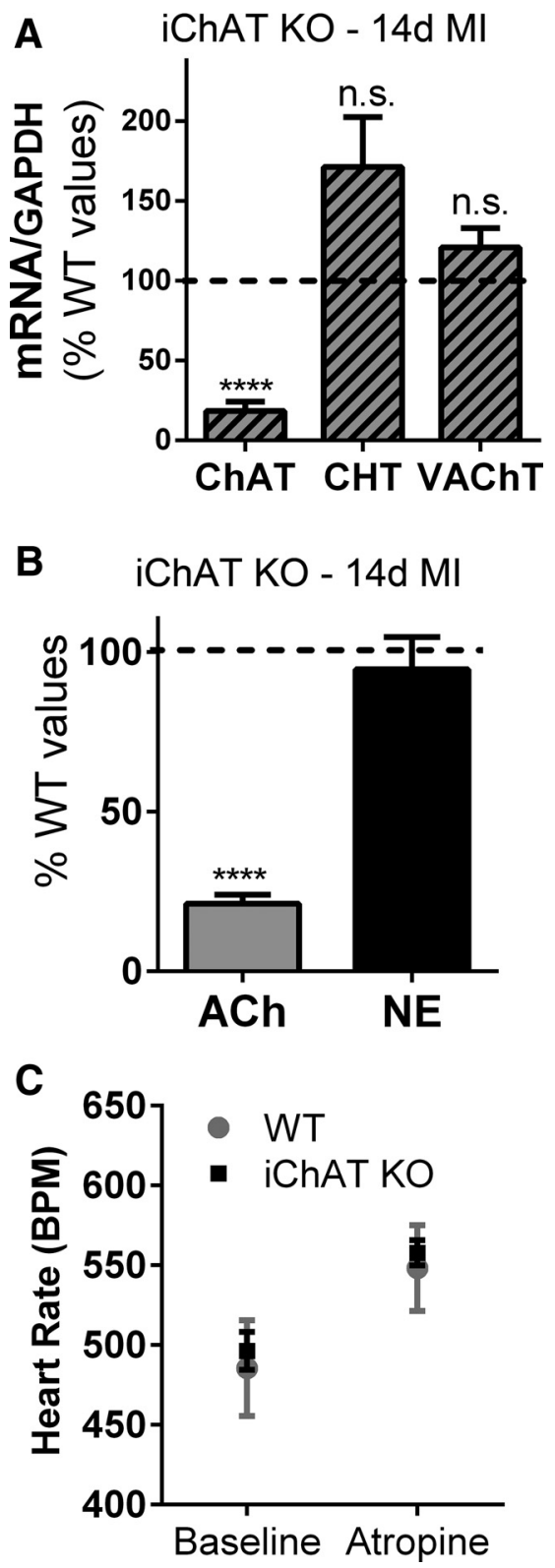

Figure 4. Deletion of $\mathrm{ChAT}$ in adult sympathetic neurons prevents the increase in left ventricle ACh after Ml. $A$, Expression of cholinergic genes. ChAT, CHT, and VAChT mRNA were quantified $14 \mathrm{~d}$ after Ml in ChAT ${ }^{\text {DBHCreERT2/lox }}$ mice that had been treated with tamoxifen for $7 \mathrm{~d}$ (iChAT KO) and normalized to GAPDH mRNA in the same samples. Data are graphed as a percentage of control using the levels of each gene previously observed in WT mice $14 \mathrm{~d}$ post-MI as the control values (dotted black line). ChAT mRNA was present at levels similar to sham controls and was significantly lower than WT post-MI mice, whereas $\mathrm{CHT}$ and VAChT mRNA levels were not significantly different from WT mice after MI. B, Ventricular ACh and NE. The loss of the ChAT gene in sympathetic neurons resulted in ACh levels $14 \mathrm{~d}$ after MI that were similar to sham hearts and significantly lower than the post-MI levels previously identified in WT mice (dotted black line). NE levels were unchanged compared with WT mice. Data are shown as means \pm SEM; $n=4 ;{ }^{* * * *} p<0.0001$ compared with WT $14 \mathrm{~d}$ post-MI. C, Parasympathetic control of heart rate. Heart rate was quantified in unoperated WT and iChAT KO mice before and after atropine injection (mean $\pm \mathrm{SEM}, n=3$ ).

in sympathetic neurons requires the nuclear matrix protein Satb2, which is not involved in the induction of cholinergic genes by other growth factors (Apostolova et al., 2010). Therefore, we also quantified Satb2 mRNA in WT and gp130 KO ganglia. Three days after MI, cholinergic genes were not increased compared with shams (data not shown), but $7 \mathrm{~d}$ after MI, the mRNAs en-
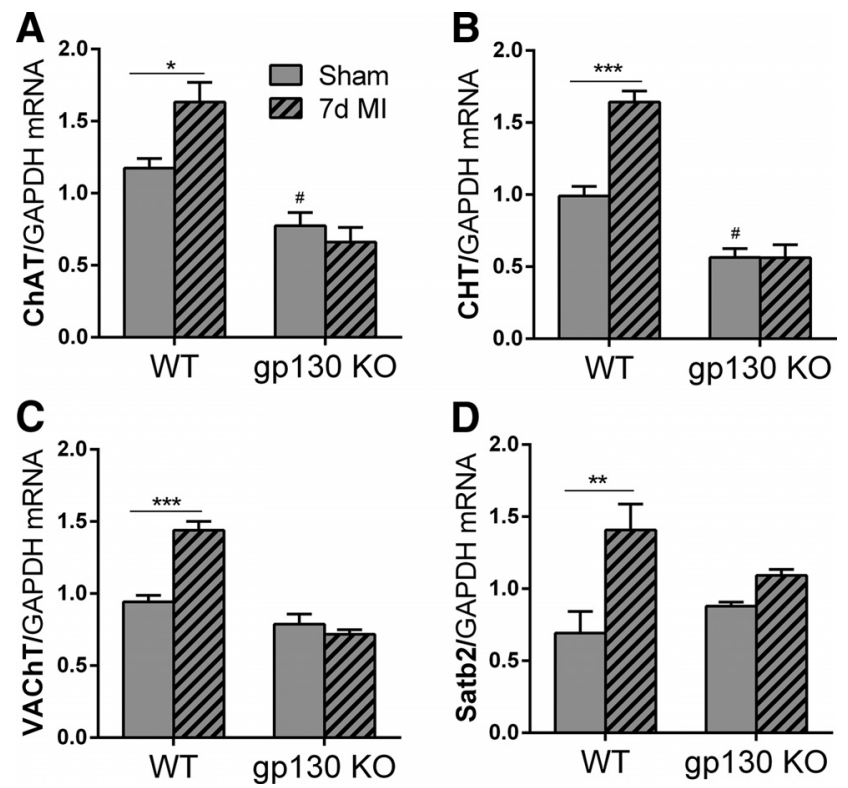

Figure 5. Neuronal gp130 is required for cholinergic gene expression after MI. ChAT $(\boldsymbol{A})$, CHT $(\boldsymbol{B})$, VAChT $(\boldsymbol{C})$, and Satb2 (D) mRNA were quantified in WT and neuronal gp130 K0 (hashed bars) stellate ganglia $7 \mathrm{~d}$ after sham surgery or MI. Data are shown as means $\pm \mathrm{SEM} ; n=4$ except WT $7 \mathrm{~d} \mathrm{MI} n=3$; ${ }^{*} p<0.05,{ }^{* *} p<0.01,{ }^{* * *} p<0.001$ compared with sham of the same genotype; \#p $<0.05$ compared with sham WT (two-way ANOVA).

coding ChAT, CHT, VAChT, and Satb2 were all increased significantly in WT neurons, but not in neurons lacking gp130 (Fig. 5). These data suggest that inflammatory cytokines stimulate ACh production in cardiac sympathetic neurons after acute MI, just as they do in nonischemic heart failure (Kanazawa et al., 2010). In addition, basal levels of CHT and ChAT mRNA were significantly lower in the gp130 KO stellates than in the WT stellates.

To understand the functional consequences of cholinergic sympathetic transmission in the heart, we first investigated the effect of exogenous neurotransmitters in a normal heart. The transmural (epicardial to endocardial) gradient in APD is critical for normal activation and repolarization of the left ventricle (Costantini et al., 2005) and the gradient in APD is matched by a transmural gradient of sympathetic innervation. Disrupting the innervation gradient in a normal heart is arrhythmogenic (Ieda et al., 2007; Lorentz et al., 2010), highlighting the importance of neuronal regulation of cardiac repolarization. To elucidate the impact of $\mathrm{NE}$ and $\mathrm{ACh}$, we focused on regulation of $\mathrm{APD}$ and calcium release using a standard S1-S2 pacing protocol. Control hearts were paced under baseline conditions and then adrenergic effects on APD restitution and CaTs were investigated using $1.5 \mu \mathrm{M}$ NE in the absence or presence of 1.5 $\mu \mathrm{M}$ ACh. Global application of NE decreased APD across all pacing intervals, consistent with allowing the ventricle to adapt to the higher heart rates present during sympathetic stimulation. The addition of ACh together with NE resulted in APDs that were somewhat longer (Fig. $6 A, C$ ), which would likely make it harder for the heart to adapt to higher heart rates and may increase the likelihood of arrhythmia. Application of $\mathrm{NE}$ also increased CaT amplitude after a premature stimulus (Fig. $6 B, D$ ), whereas coapplication of ACh with NE reduced the CaT amplitude back toward baseline levels, suggesting that cardiac contractility would be blunted with co-release of ACh and $\mathrm{NE}$. 


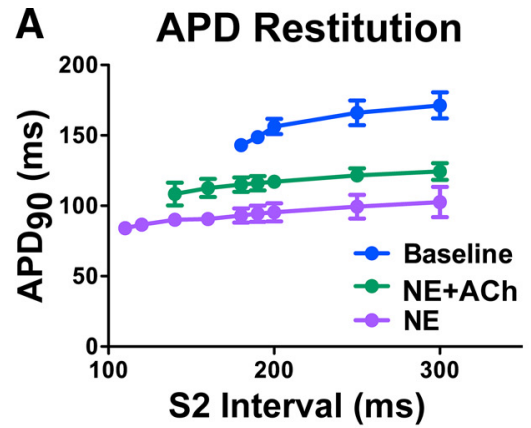

\section{Example AP Traces}

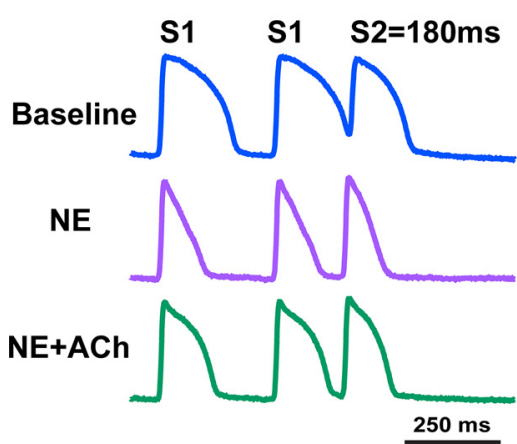

B Calcium Transients

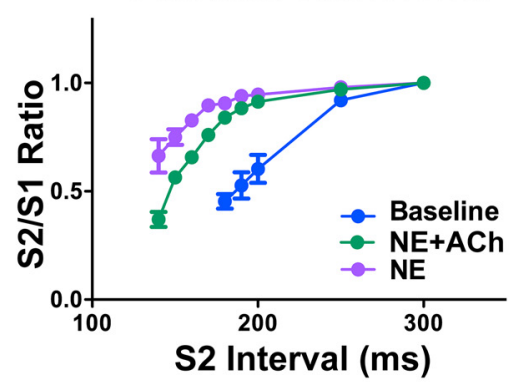

D Example $\mathrm{Ca}^{2+}$ Transients

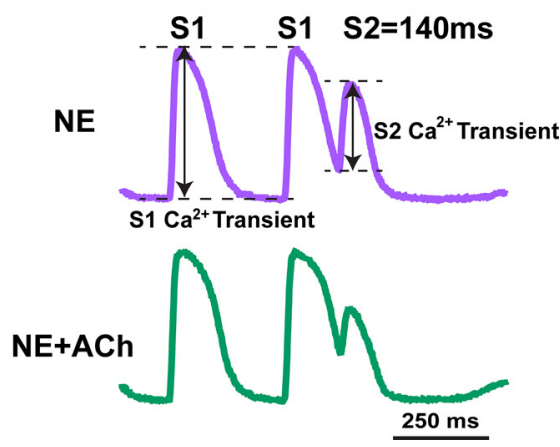

Figure 6. Functional effects of $\mathrm{NE}$ and $\mathrm{ACh}$ co-release. $\boldsymbol{A}, \boldsymbol{C}$, Application of $\mathrm{NE}(1.5 \mu \mathrm{m})$ alone dramatically shortens $\mathrm{APD}_{90}$ at all premature (S2) pacing intervals to allow the heart to quickly adapt to high heart rates during sympathetic activity. Coapplication of $A C h(1.5 \mu \mathrm{m})$ does not allow the $\mathrm{APD}_{90}$ to shorten to the same extent, which may lead to arrhythmia. $B, D$, Application of NE alone also increased the size of CaTs after premature stimuli (increased S2/S1 ratio), whereas coapplication of ACh reduced the effect of NE $(\boldsymbol{B}, \boldsymbol{D})$. The $\mathrm{S} 2 / \mathrm{S} 1$ ratio was calculated as the S2 CaT amplitude divided by S1 CaT amplitude $(\boldsymbol{D})$. Data are shown as means $\pm \mathrm{SEM} ; n=3$.

\section{Discussion}

Our data indicate that cardiac sympathetic neurons transiently produce ACh together with NE in the weeks after MI. Several lines of evidence suggest that the increase in ACh content observed in viable heart tissue after $\mathrm{MI}$ is due to the induction of $\mathrm{ACh}$ in sympathetic nerves rather than increased production by parasympathetic nerves. First, there are few parasympathetic fibers detectable in the mouse left ventricle, in contrast to robust innervation to the SA node and cardiac conduction system (Mabe et al., 2006), and functional studies indicate that stimulating cardiac parasympathetic nerves has little impact on contractility of the left ventricle (Matsuura et al., 1997; Takahashi et al., 2003; Brack et al., 2010). Second, the transient increase in cardiac ACh content coincided with increased expression of the genes required for ACh production in the stellate ganglion and the appearance of ChAT and VAChT protein in $\mathrm{TH}+$ cardiac sympathetic neurons. Third, selective deletion of the ChAT gene in adult sympathetic neurons prevented the increase in cardiac ACh content after MI. These data are consistent with ACh production in cardiac sympathetic nerves after MI, which is interesting because cholinergic properties have also been observed in adult sympathetic neurons during heart failure (Kanazawa et al., 2010), but have not been seen in other injury paradigms, including axotomy (Boeshore et al., 2004; Wojtkiewicz et al., 2013) and inflammatory colitis (Skobowiat et al., 2010).

The large fraction of neurons within the stellate ganglion projecting to the heart facilitate use of this model to track changes in neurotransmitter phenotype. Approximately $92 \%$ of rat stellate neurons project to the heart (Pardini et al., 1989), so mRNA isolated from rodent stellate ganglia is primarily from cardiac neurons. Therefore, it is not surprising that we were able to detect increases in cholinergic genes within the stellate after MI and widespread coexpression of ChAT protein in $\mathrm{TH}+$ neurons. Most of these cholinergic sympathetic neurons project to the heart, consistent with the increase in ACh content in the heart and identification of VAChT in $\mathrm{TH}+$ axons within the heart. However, some of the noncardiac neurons in stellate ganglia project to sweat glands in the front paws, which also have a $\mathrm{TH}+/ \mathrm{ChAT}+$ phenotype in the mouse (Guidry and Landis, 1995, 1998). These neurons were relatively rare and were also observed in sham ganglia (data not shown).

The acquisition of cholinergic function required expression of the gp130 cytokine receptor in sympathetic neurons, suggesting that retrograde signaling by target-derived cytokines induced the acquisition of a cholinergic neurotransmitter phenotype in adult sympathetic neurons. This was further supported by the HPLC analysis Satb2 mRNA within the stellate ganglia because Satb2 mediates cytokine stimulation of cholinergic genes in sympathetic neurons, but is not involved in the induction of cholinergic genes by other factors (Apostolova et al., 2010). Previous studies have shown that removal of gp130 from sympathetic neurons also prevents the local suppression of noradrenergic transmission in the left ventricle after acute MI (Parrish et al., 2010) and induction of cholinergic transmission in heart failure (Kanazawa et al., 2010). Together, these data suggest that retrograde signaling by gp130 in adult neurons can alter sympathetic neurotransmitter phenotype in a manner similar to the gp130dependent noradrenergic to cholinergic conversion of sympathetic neurons innervating developing sweat glands (Stanke et al., 2006).

A technical advance of our study was the development of a method to quantify cholinergic and noradrenergic properties simultaneously by measuring $\mathrm{NE}$ and $\mathrm{ACh}$ within the same heart tissue. Sensitive HPLC assays for NE and other catecholamines have been available for many years, but it was not possible to quantify ACh directly until the recent development of a sensitive mass spectrometry assay. Therefore, cholinergic function in the past was assayed indirectly by measuring ChAT activity in tissue homogenates (Schotzinger and Landis, 1988) or by the lack of a potassium permanganate precipitate in EM analysis of vesicles (Landis, 1976; Kanazawa et al., 2010). The advent of a sensitive assay for ACh has allowed us to quantify both NE and ACh in the same tissue and thus track relative changes over time. Our earlier studies of the post-MI ventricle-quantified NE content in the entire left ventricle (Li et al., 2004; Parrish et al., 2010; Lorentz et al., 2011), but newer data indicate that the scar remains denervated for an extended period of time after ischemia-reperfusion (Gardner and Habecker, 2013). Therefore, we dissected scar tissue away from the viable innervated left ventricle before analysis of $\mathrm{NE}$ and $\mathrm{ACh}$ for these studies. One consequence was a delay in 
freezing the tissue, which resulted in a small loss of ACh due to metabolism by acetylcholinesterase. This was not the case for NE, which was more stable. To control for the degradation of $\mathrm{ACh}$, tissue from sham hearts was processed in the same way as infarcted hearts so that any loss of ACh would be comparable across all groups. Therefore, we are confident that the relative changes in ACh content reported here are accurate, but the exact levels of ACh reported may underestimate the amount present in vivo.

The functional consequences of sympathetic cholinergic transmission in the heart are not yet understood. Many functional studies have been performed in mice with noradrenergic neurons that lack gp130 (Parrish et al., 2008; Parrish et al., 2010; Kanazawa et al., 2010), but removal of gp130 from all DBH-expressing cells does not simply prevent the acquisition of cholinergic function in sympathetic neurons innervating the heart. Constitutive noradrenergic gp130 knock-out mice have autonomic imbalance due to disrupted central autonomic control (Parrish et al., 2009), elevated ACh content in cardiac parasympathetic nerves (Hasan et al., 2012), altered neuropeptide expression after MI (Alston et al., 2011), and impaired axon regeneration (Pellegrino and Habecker, 2013). Importantly, the promiscuous expression of $\mathrm{DBH}$ in neural crest cells results in the deletion of target genes in cardiac parasympathetic neurons as well as sympathetic neurons (Parrish et al., 2009), necessitating the change to the inducible DBH-CreERT2 that does not generate recombination in parasympathetic neurons (Stubbusch et al., 2011). Therefore, elucidating the role of sympathetic cholinergic transmission after MI will require detailed functional studies in iChAT KO mice, which have not yet been characterized.

As a first test to elucidate the impact of combined noradrenergic and cholinergic transmission in the ventricle, we examined the effect of global NE and ACh on cardiac APD and calcium transients. Activating cardiac $\beta$ receptors with exogenous NE decreased APD and flattened the slope of the APD restitution curve, consistent with previous studies (Hartzell, 1988). The shallower slope of the APD restitution curve at short cycle lengths is suggestive of decreased arrhythmia propensity (Nash et al., 2006; Selvaraj et al., 2007) and allows the heart to function properly at high heart rates. Likewise, NE increased the size of myocyte CaTs after a premature stimuli, which normally produce small transients due to refractory ryanodine receptors and low calcium stores within the sarcoplasmic reticulum (SR). NE activation of $\beta$ receptors stimulates faster recovery of ryanodine receptors and enhanced filling of SR calcium stores by the SR calcium transport ATPase, resulting in larger CaTs and increased cardiac contractility even at high heart rates. Coadministration of ACh with NE blunted the NE-stimulated increase in CaT and increased APD, suggesting decreased contractility and impaired adaptation to fast heart rates when ACh is present together with NE. This contrasts with the normal situation of ACh release only from parasympathetic nerves, which strongly decreases heart rate and has limited direct effect on ventricular APD (Matsuura et al., 1997; Brack et al., 2010).

Together, our data indicate that cardiac sympathetic nerves produce ACh in addition to NE after MI. The production of $\mathrm{ACh}$ is transient and corresponds to a period of cardiac remodeling that is characterized by high levels of inflammatory cytokines and macrophages within the heart and includes a period of particularly high arrhythmia risk. The induction of cholinergic genes requires expression of the gp130 cytokine receptor in sympathetic neurons, suggesting that retrograde signaling by heart-derived cytokines stimulates the acquisition of the cholinergic phenotype. The functional consequences of cholinergic sympathetic transmission remain unclear, but our data suggest that release of ACh together with NE from sympathetic nerves may impair adaptation to fast heart rates and increase arrhythmia propensity.

\section{References}

Alston EN, Parrish DC, Hasan W, Tharp K, Pahlmeyer L, Habecker BA (2011) Cardiac ischemia-reperfusion regulates sympathetic neuropeptide expression through gp130-dependent and independent mechanisms. Neuropeptides 45:33-42. CrossRef Medline

Aoyama T, Takimoto Y, Pennica D, Inoue R, Shinoda E, Hattori R, Yui Y, Sasayama S (2000) Augmented expression of cardiotrophin-1 and its receptor component, gp130, in both left and right ventricles after myocardial infarction in the rat. J Mol Cell Cardiol 32:1821-1830. CrossRef Medline

Apostolova G, Dorn R, Ka S, Hallböök F, Lundeberg J, Liser K, Hakim V, Brodski C, Michaelidis TM, Dechant G (2007) Neurotransmitter phenotype-specific expression changes in developing sympathetic neurons. Mol Cell Neurosci 35:397-408. CrossRef Medline

Apostolova G, Loy B, Dorn R, Dechant G (2010) The sympathetic neurotransmitter switch depends on the nuclear matrix protein Satb2. J Neurosci 30:16356-16364. CrossRef Medline

Asmus SE, Parsons S, Landis SC (2000) Developmental changes in the transmitter properties of sympathetic neurons that innervate the periosteum. J Neurosci 20:1495-1504. Medline

Boeshore KL, Schreiber RC, Vaccariello SA, Sachs HH, Salazar R, Lee J, Ratan RR, Leahy P, Zigmond RE (2004) Novel changes in gene expression following axotomy of a sympathetic ganglion: a microarray analysis. J Neurobiol 59:216-235. CrossRef Medline

Brack KE, Coote JH, Ng GA (2010) Vagus nerve stimulation inhibits the increase in $\mathrm{Ca} 2+$ transient and left ventricular force caused by sympathetic nerve stimulation but has no direct effects alone-epicardial Ca2+ fluorescence studies using fura-2 AM in the isolated innervated beating rabbit heart. Exp Physiol 95:80-92. CrossRef Medline

Brodski C, Schnürch H, Dechant G (2000) Neurotrophin-3 promotes the cholinergic differentiation of sympathetic neurons. Proc Natl Acad Sci U S A 97:9683-9688. CrossRef Medline

Brodski C, Schaubmar A, Dechant G (2002) Opposing functions of GDNF and NGF in the development of cholinergic and noradrenergic sympathetic neurons. Mol Cell Neurosci 19:528-538. CrossRef Medline

Brumovsky PR, Seroogy KB, Lundgren KH, Watanabe M, Hökfelt T, Gebhart GF (2011) Some lumbar sympathetic neurons develop a glutamatergic phenotype after peripheral axotomy with a note on VGLUT(2)-positive perineuronal baskets. Exp Neurol 230:258-272. CrossRef Medline

Buffelli M, Burgess RW, Feng G, Lobe CG, Lichtman JW, Sanes JR (2003) Genetic evidence that relative synaptic efficacy biases the outcome of synaptic competition. Nature 424:430-434. CrossRef Medline

Costantini DL, Arruda EP, Agarwal P, Kim KH, Zhu Y, Zhu W, Lebel M, Cheng CW, Park CY, Pierce SA, Guerchicoff A, Pollevick GD, Chan TY, Kabir MG, Cheng SH, Husain M, Antzelevitch C, Srivastava D, Gross GJ, Hui CC, et al. (2005) The homeodomain transcription factor Irx5 establishes the mouse cardiac ventricular repolarization gradient. Cell 123: 347-358. CrossRef Medline

Frangogiannis NG (2012) Regulation of the inflammatory response in cardiac repair. Circ Res 110:159-173. CrossRef Medline

Furlan A, Lübke M, Adameyko I, Lallemend F, Ernfors P (2013) The transcription factor Hmxl and growth factor receptor activities control sympathetic neurons diversification. EMBO J 32:1613-1625. CrossRef Medline

Furshpan EJ, MacLeish PR, O'Lague PH, Potter DD (1976) Chemical transmission between rat sympathetic neurons and cardiac myocytes developing in microcultures: evidence for cholinergic, adrenergic, and dualfunction neurons. Proc Natl Acad Sci U S A 73:4225-4229. CrossRef Medline

Gardner RT, Habecker BA (2013) Infarct-derived chondroitin sulfate proteoglycans prevent sympathetic reinnervation after cardiac ischemia-reperfusion injury. J Neurosci 33:7175-7183. CrossRef Medline

Gritman K, Van Winkle DM, Lorentz CU, Pennica D, Habecker BA (2006) The lack of cardiotrophin-1 alters expression of interleukin- 6 and leuke- 
mia inhibitory factor mRNA but does not impair cardiac injury response. Cytokine 36:9-16. CrossRef Medline

Guidry G, Landis SC (1995) Sympathetic axons pathfind successfully in the absence of target. J Neurosci 15:7565-7574. Medline

Guidry G, Landis SC (1998) Target-dependent development of the vesicular acetylcholine transporter in rodent sweat gland innervation. Dev Biol 199: 175-184. CrossRef Medline

Habecker BA, Pennica D, Landis SC (1995) Cardiotrophin-1 is not the sweat gland-derived differentiation factor. Neuroreport 7:41-44. CrossRef Medline

Haghikia A, Stapel B, Hoch M, Hilfiker-Kleiner D (2011) STAT3 and cardiac remodeling. Heart Fail Rev 16:35-47. CrossRef Medline

Hartzell HC (1988) Regulation of cardiac ion channels by catecholamines, acetylcholine and second messenger systems. Prog Biophys Mol Biol 52: 165-247. CrossRef Medline

Hasan W, Woodward WR, Habecker BA (2012) Altered atrial neurotransmitter release in transgenic p75 (-/-) and gp130 KO mice. Neurosci Lett 529:55-59. CrossRef Medline

Hesp ZC, Zhu Z, Morris TA, Walker RG, Isaacson LG (2012) Sympathetic reinnervation of peripheral targets following bilateral axotomy of the adult superior cervical ganglion. Brain Res 1473:44-54. CrossRef Medline

Hiltunen JO, Laurikainen A, Väkevä A, Meri S, Saarma M (2001) Nerve growth factor and brain-derived neurotrophic factor mRNAs are regulated in distinct cell populations of rat heart after ischaemia and reperfusion. J Pathol 194:247-253. CrossRef Medline

Hiltunen PH, Airaksinen MS (2004) Sympathetic cholinergic target innervation requires GDNF family receptor GFR[alpha]2. Mol Cell Neurosci 26:450-457. CrossRef Medline

Hyatt-Sachs H, Bachoo M, Schreiber R, Vaccariello SA, Zigmond RE (1996) Chemical sympathectomy and postganglionic nerve transection produce similar increases in galanin and VIP mRNA but differ in their effects on peptide content. J Neurobiol 30:543-555. Medline

Ieda M, Kanazawa H, Kimura K, Hattori F, Ieda Y, Taniguchi M, Lee JK, Matsumura K, Tomita Y, Miyoshi S, Shimoda K, Makino S, Sano M, Kodama I, Ogawa S, Fukuda K (2007) Sema3a maintains normal heart rhythm through sympathetic innervation patterning. Nat Med 13: 604-612. CrossRef Medline

Kanazawa H, Ieda M, Kimura K, Arai T, Kawaguchi-Manabe H, Matsuhashi T, Endo J, Sano M, Kawakami T, Kimura T, Monkawa T, Hayashi M, Iwanami A, Okano H, Okada Y, Ishibashi-Ueda H, Ogawa S, Fukuda K (2010) Heart failure causes cholinergic transdifferentiation of cardiac sympathetic nerves via gp130-signaling cytokines in rodents. J Clin Invest 120:408-421. CrossRef Medline

Klimaschewski L, Grohmann I, Heym C (1996) Target-dependent plasticity of galanin and vasoactive intestinal peptide in the rat superior cervical ganglion after nerve lesion and re-innervation. Neuroscience 72:265-272. CrossRef Medline

Landis SC (1976) Rat sympathetic neurons and cardiac myocytes developing in microcultures: correlation of the fine structure of endings with neurotransmitter function in single neurons. Proc Natl Acad Sci U S A 73:4220-4224. CrossRef Medline

Li W, Knowlton D, Van Winkle DM, Habecker BA (2004) Infarction alters both the distribution and noradrenergic properties of cardiac sympathetic neurons. Am J Physiol Heart Circ Physiol 286:H2229-H2236. CrossRef Medline

Lorentz CU, Alston EN, Belcik T, Lindner JR, Giraud GD, Habecker BA (2010) Heterogeneous ventricular sympathetic innervation, altered \{beta\} adrenergic receptor expression, and rhythm instability in mice lacking p75 neurotrophin receptor. Am J Physiol Heart Circ Physiol 298: H1652-H1660. CrossRef Medline

Lorentz CU, Woodward WR, Tharp K, Habecker BA (2011) Altered norepinephrine content and ventricular function in p75NTR-/- mice after myocardial infarction. Auton Neurosci 164:13-19. CrossRef Medline

Mabe AM, Hoard JL, Duffourc MM, Hoover DB (2006) Localization of cholinergic innervation and neurturin receptors in adult mouse heart and expression of the neurturin gene. Cell Tissue Res 326:57-67. CrossRef Medline

Matsuura W, Sugimachi M, Kawada T, Sato T, Shishido T, Miyano H, Nakahara T, Ikeda Y, Alexander J Jr, Sunagawa K (1997) Vagal stimulation decreases left ventricular contractility mainly through negative chronotropic effect. Am J Physiol 273:H534-H539. Medline

Miwa K, Lee JK, Takagishi Y, Opthof T, Fu X, Kodama I (2010) Glial cell line-derived neurotrophic factor (GDNF) enhances sympathetic neurite growth in rat hearts at early developmental stages. Biomed Res 31: 353-361. CrossRef Medline

Myles RC, Wang L, Kang C, Bers DM, Ripplinger CM (2012) Local betaadrenergic stimulation overcomes source-sink mismatch to generate focal arrhythmia. Circ Res 110:1454-1464. CrossRef Medline

Nash MP, Bradley CP, Sutton PM, Clayton RH, Kallis P, Hayward MP, Paterson DJ, Taggart P (2006) Whole heart action potential duration restitution properties in cardiac patients: a combined clinical and modelling study. Exp Physiol 91:339-354. CrossRef Medline

Oba T, Yasukawa H, Hoshijima M, Sasaki K, Futamata N, Fukui D, Mawatari K, Nagata T, Kyogoku S, Ohshima H, Minami T, Nakamura K, Kang D, Yajima T, Knowlton KU, Imaizumi T (2012) Cardiac-specific deletion of SOCS-3 prevents development of left ventricular remodeling after acute myocardial infarction. J Am Coll Cardiol 59:838-852. CrossRef Medline

Pardini BJ, Lund DD, Schmid PG (1989) Organization of the sympathetic postganglionic innervation of the rat heart. J Auton Nerv Syst 28:193-201. CrossRef Medline

Parrish DC, Gritman K, Van Winkle DM, Woodward WR, Bader M, Habecker BA (2008) Postinfarct sympathetic hyperactivity differentially stimulates expression of tyrosine hydroxylase and norepinephrine transporter. Am J Physiol Heart Circ Physiol 294:H99-H106. Medline

Parrish DC, Alston EN, Rohrer H, Nkadi P, Woodward WR, Schütz G, Habecker BA (2010) Infarction-induced cytokines cause local depletion of tyrosine hydroxylase in cardiac sympathetic nerves. Exp Physiol 95: 304-314. Medline

Parrish DC, Alston EN, Rohrer H, Hermes SM, Aicher SA, Nkadi P, Woodward WR, Stubbusch J, Gardner RT, Habecker BA (2009) The absence of gp130 in dopamine \{beta\} hydroxylase-expressing neurons leads to autonomic imbalance and increased reperfusion arrhythmias. Am J Physiol Heart Circ Physiol 297:H960-H967. CrossRef Medline

Pellegrino MJ, Habecker BA (2013) STAT3 integrates cytokine and neurotrophin signals to promote sympathetic axon regeneration. Mol Cell Neurosci 56:272-282. CrossRef Medline

Rao MS, Sun Y, Escary JL, Perreau J, Tresser S, Patterson PH, Zigmond RE, Brulet P, Landis SC (1993) Leukemia inhibitory factor mediates an injury response but not a target- directed developmental transmitter switch in sympathetic neurons. Neuron 11:1175-1185. CrossRef Medline

Reichardt LF, Patterson PH (1977) Neurotransmitter synthesis and uptake by isolated sympathetic neurones in microcultures. Nature 270:147-151. CrossRef Medline

Schäfer MK, Schütz B, Weihe E, Eiden LE (1997) Target-independent cholinergic differentiation in the rat sympathetic nervous system. Proc Natl Acad Sci U S A 94:4149-4154. CrossRef Medline

Schotzinger RJ, Landis SC (1988) Cholinergic phenotype developed by noradrenergic sympathetic neurons after innervation of a novel cholinergic target in vivo. Nature 335:637-639. CrossRef Medline

Schotzinger RJ, Landis SC (1990) Acquisition of cholinergic and peptidergic properties by sympathetic innervation of rat sweat glands requires interaction with normal target. Neuron 5:91-100. CrossRef Medline

Selvaraj RJ, Picton P, Nanthakumar K, Chauhan VS (2007) Steeper restitution slopes across right ventricular endocardium in patients with cardiomyopathy at high risk of ventricular arrhythmias. Am J Physiol Heart Circ Physiol 292:H1262-H1268. Medline

Shi X, Habecker BA (2012) gp130 cytokines stimulate proteasomal degradation of tyrosine hydroxylase via extracellular signal regulated kinases 1 and 2. J Neurochem 120:239-247. CrossRef Medline

Skobowiat C, Gonkowski S, Calka J (2010) Phenotyping of sympathetic chain ganglia (SChG) neurons in porcine colitis. J Vet Med Sci 72: 1269-1274. CrossRef Medline

Solomon SD, Zelenkofske S, McMurray JJ, Finn PV, Velazquez E, Ertl G, Harsanyi A, Rouleau JL, Maggioni A, Kober L, White H, Van de Werf F, Pieper K, Califf RM, Pfeffer MA; Valsartan in Acute Myocardial Infarction Trial (VALIANT) Investigators (2005) Sudden death in patients with myocardial infarction and left ventricular dysfunction, heart failure, or both. N Engl J Med 352:2581-2588. CrossRef Medline

Stanke M, Duong CV, Pape M, Geissen M, Burbach G, Deller T, Gascan H, Otto C, Parlato R, Schütz G, Rohrer H (2006) Target-dependent specification of the neurotransmitter phenotype: cholinergic differentiation of sympathetic neurons is mediated in vivo by gp 130 signaling. Development 133:141-150. CrossRef Medline 
Stubbusch J, Majdazari A, Schmidt M, Schütz G, Deller T, Rohrer H (2011) Generation of the tamoxifen-inducible DBH-Cre transgenic mouse line DBH-CT. Genesis 49:935-941. CrossRef Medline

Sun Y, Zigmond RE (1996) Involvement of leukemia inhibitory factor in the increases in galanin and vasoactive intestinal peptide mRNA and the decreases in neuropeptide $\mathrm{Y}$ and tyrosine hydroxylase mRNA in sympathetic neurons after axotomy. J Neurochem 67:1751-1760. Medline

Takahashi H, Maehara K, Onuki N, Saito T, Maruyama Y (2003) Decreased contractility of the left ventricle is induced by the neurotransmitter acetylcholine, but not by vagal stimulation in rats. Jpn Heart J 44:257-270. CrossRef Medline
Wojtkiewicz J, Równiak M, Crayton R, Gonkowski S, Robak A, Zalecki M, Majewski M, Klimaschewski L (2013) Axotomy-induced changes in the chemical coding pattern of colon projecting calbindin-positive neurons in the inferior mesenteric ganglia of the pig. J Mol Neurosci 51:99-108. CrossRef Medline

Yamamori T, Fukada K, Aebersold R, Korsching S, Fann MJ, Patterson PH (1989) The cholinergic neuronal differentiation factor from heart cells is identical to leukemia inhibitory factor. Science 246:1412-1416. CrossRef Medline

Zigmond RE, Sun Y (1997) Regulation of neuropeptide expression in sympathetic neurons: paracrine and retrograde influences. Ann NY Acad Sci 814:181-197. CrossRef Medline 